\title{
Blood and Milk Glutamine + Glutamate and Milk Composition in Lactating Holstein Cows in Semi-Arid of Brazil
}

\author{
Joyci Torres d'Paula', Rafael Leonardo Vargas Martinez'2, \\ Telga Lucena de Almeida Craveiro Alves' ${ }^{1}$, Stephania Katurchi Mendes Méloㄹ, \\ Marianne Kutschenko3 ${ }^{3}$ Eduardo Terra Nogueira ${ }^{3}$, \\ Helena Emília Cavalcanti da Costa Cordeiro Manso', Hélio Cordeiro Manso Filho ${ }^{{ }^{*}}$ \\ ${ }^{1}$ Departamento de Zootecnia, Universidade Federal Rural de Pernambuco, Recife, Brazil \\ ${ }^{2}$ Associação Pernambucana dos Criadores, Recife, Brazil \\ ${ }^{3}$ Ajinomoto do Brasil, São Paulo, Brazil \\ Email: ${ }^{*}$ hmanso@dz.ufrpe.br
}

Received 7 November 2014; revised 3 December 2014; accepted 24 December 2014

Copyright (C) 2014 by authors and Scientific Research Publishing Inc.

This work is licensed under the Creative Commons Attribution International License (CC BY). http://creativecommons.org/licenses/by/4.0/

(c) (i) Open Access

\begin{abstract}
Our objectives were to measure glutamine (Gln) and glutamate (Glu) concentrations in the milk and blood of lactating Holstein cows, as well as milk composition and somatic cell count (SCC) throughout different stages of lactation. Samples were collected from 21 cows in the $1^{\text {st }}, 2^{\text {nd }}, 3^{\text {rd }}, 5^{\text {th }}$ and $10^{\text {th }}$ months of lactation. It analyzed Gln and Glu in the blood and Gln, Glu, lactose, fat, protein and somatic cells in the milk. Also, it measured Gln and Glu in blood from these dairy cows' calves. Results were analyzed using one-way ANOVA, T-test and Tukey's test, with a 5\% significance level. There was a difference in blood [GIn] in from dairy cows $(P<0.05)$, with lost concentration observed at $2^{\text {nd }}(\sim 0.181 \mu \mathrm{mol} / \mathrm{mL})$ and $5^{\text {th }}(\sim 0.190 \mu \mathrm{mol} / \mathrm{mL})$ months of lactation and the highest at $10^{\text {th }}$ month $(\sim 0.276 \mu \mathrm{mol} / \mathrm{mL})$. Also there was a higher protein content in the $5^{\text {th }}$ and $10^{\text {th }}$ months of lactation $(\sim 3.61 \%$ each) when compared to the other months $(P<0.05)$. There was no difference in calves' parameters and in all others parameters from dairy cows. We concluded that the lactation period produced a significant interference in blood [GIn] but not in milk [Gln] which may indicate increase in utilization or decrease in production of this amino acids during lactation in these cows under tropical conditions.
\end{abstract}

\section{Keywords}

Amino Acid, Lactation, Bovine, Ruminant

\footnotetext{
${ }^{*}$ Corresponding author.
}

How to cite this paper: d'Paula, J.T., et al. (2014) Blood and Milk Glutamine + Glutamate and Milk Composition in Lactating Holstein Cows in Semi-Arid of Brazil. Open Journal of Veterinary Medicine, 4, 322-328. 


\section{Introduction}

A series of physiologic adaptations occur in the dairy cows at the start of lactation, which favor milk production in detriment of other metabolic activities, such as: maintenance, growth, reproductive activity, and fetal growth. These characteristics are related with changes in hormone serum levels, favoring the supply of nutrients to the mammary glands in detriment of other tissues [1]. Also, lactation period can represent a catabolic state in which muscular protein is mobilized to meet the female's demands [2]. High production animals secrete over $1 \mathrm{~kg}$ of protein in their milk per day, which corresponds to more than $30 \%$ of plasma proteins [3], contributing for increase in protein body's reserve utilization.

Glutamine (Gln) and glutamate (Glu) are the main free amino acids in the plasma and milk. Different authors identified a decrease of $25 \%$ to $33 \%$ in glutamine plasma levels during lactation, which had been considered a limitation for milk production [4]. Under normal conditions, glutamine is a non-essential amino acid synthesized by various tissues and organs [5], such as muscle, brain, placenta, perivenous hepatocytes, which have the enzyme glutamine synthetase (GS), and also pulmonary endothelial cells which contain glutamate dehydrogenase (GDH). However, the cells that are primarily consumers of glutamine are cells of the intestinal mucosa, leukocytes, type II pneumocytes, periportal hepatocytes, and renal tubule cells, which have a high glutaminase activity [6].

The plasma and tissue concentrations of glutamine decrease in situations of clinical stress and catabolism. For example, during the lactation there is an elevated consume of this amino acid when compared with the rate of synthesis and its release by the skeletal muscle [7]. Indeed, there is little information about Gln and Glu metabolism in dairy cows under tropical conditions. Therefore, our objective was to describe possible variations in the concentration of Gln and Glu in blood and milk of dairy cows, as well as their milk production and composition during lactation.

\section{Material and Methods}

\subsection{Animals and Their Management}

A total of 21 Holstein lactating cows and their calves were included in this study, from two farms from the Agreste region of the state of Pernambuco, located in Gravatá (n = 11) (08¹2'04"S; 35 33'53"W) and São Bento do Una $(\mathrm{n}=10)\left(08^{\circ} 31^{\prime} 22^{\prime \prime S}\right.$; 36 $\left.26^{\prime} 40^{\prime \prime} \mathrm{W}\right)$. The cows were kept in an intensive farming system and received similar feed, which included $12 \mathrm{~kg}$ /day of mixed food concentrate with $24 \%$ protein, with include palm (Opuntia cochenillifera), cassava leaves (Manihot esculenta), corn silage, and Cynodon nlemfuensis hay. Mineral salt and water were ad libidum. The cows were milked twice daily, 5 am and $4 \mathrm{pm}$, using a milking machine. The calves were housed in individual pens, where received $2 \mathrm{~kg} / \mathrm{milk} /$ day and $2 \mathrm{~kg} /$ day of concentrate plus Cynodon nlemfuensis hay. The dairy cows had a body score between 2.0 and 3.0 in the scale, where 1.0 represents cachectic animals; 3.0, an ideal body score; and 5.0, obese animals [8]. The average age of the animals was 4.5 years old. This study was approved by the Ethics Committee for Animal Experimentation of the Universidade Federal Rural de Pernambuco (protocol number: 006184/2010).

\subsection{Blood and Milk Samples}

The blood samples from the cows were obtained from the jugular vein $(2.0 \mathrm{~mL})$ once a month, in the first, second, third, fifth, and tenth month of lactation, and the blood immediately acidified using perchloric acid (1:1) for later neutralization, as previously described [9]. The samples were transported under refrigeration to the laboratory in under $48 \mathrm{~h}$, where they were neutralized with potassium hydroxide and frozen to await analysis. Blood was collected as the cows were leaving the milking room so as to not stress the animals. In addition, it was collected venous blood $(1.0 \mathrm{~mL})$ from 21 calves with 1 and 3 months old that consume mixed milk from these cows to determine Gln and Glu.

The milk was collected at same periods of the blood samples and was used for analysis of the concentration of amino acids, milk composition, and SCC. These samples were collected in duplicates. The first one was immediately acidified for later neutralization and analysis of the concentration of amino acids, as was done with the blood samples. The second sample was collected in a specific tube containing a preservative agent (bronopol) to maintain the quality of the milk, and was used for analysis of chemical composition and somatic cell count. The milk samples were collected directly from the filter of the milking machine at the end of the morning milking. 
Results of the analysis on composition and SCC were obtained from the Official Registry of Holstein Cattle of the Breeders Association of Pernambuco.

Glutamine and glutamate concentrations were verified in deproteinized, neutralized extracts from total blood and milk, after initial conversion of glutamine into glutamate by glutaminase, and following reversion of glutamate into glutamine by the enzyme glutamic dehydrogenase, as described previously [9].

Analysis of the chemical composition of the milk included determining lactose, protein, and fat content using a Bentley $2000^{\circledR}$, from Bentley instruments. This equipment analyzed the chemical components using infrared waves. Somatic cell count was obtained using Somacount $300^{\circledR}$ (Bentley Instruments), with the results given in cells per mL. Information on milk composition and SCC were stored in the database of the Breeders Association of Pernambuco.

\subsection{Statistical Analysis}

The data was initially analyzed using the program SigmaStat ${ }^{\circledR}$, using analysis of variance (ANOVA) and t-test, both with a significance level of $5 \%(\mathrm{P}<0.05)$. The differences between the means were subsequently identified using Tukey's test, also with a significance level of $5 \%(\mathrm{P}<0.05)$. All results are expressed in mean \pm standard error.

\section{Results}

There was a statistical difference in blood [Gln] during lactation in cows, which was managed in tropical conditions, but not in blood [Glu] and blood [Gln + Glu] there was no difference $(\mathrm{P}>0.05)$ (Table 1).

Highest blood [Gln] was observed at $10^{\text {th }}$ months of lactation $(\sim 0.276 \mu \mathrm{mol} / \mathrm{mL})$ and lowest in $2^{\text {nd }}(\sim 0.181$ $\mu \mathrm{mol} / \mathrm{mL})$ and $5^{\text {th }}(\sim 0.190 \mu \mathrm{mol} / \mathrm{mL})$ months. In contrast, there is no difference in these amino acids in milk samples over the duration of the lactation period (P > 0.05; Table 1). In the calves, [Gln] and [Glu] did not change during development $(\mathrm{P}>0.05)$ and [Gln] and [Glu] were around $0.240 \mu \mathrm{mol} / \mathrm{mL}$ and $0.195 \mu \mathrm{mol} / \mathrm{mL}$ respectively (Table 2).

In addition, upon analysis of milk components, percentage of protein in the $5^{\text {th }}$ and $10^{\text {th }}$ lactation month ( $3.61 \%)$ were found to be significantly higher when compared to other three months (Table 3$)(\mathrm{P}<0.05)$. The percentage of fat was similar over the course of the lactation period, with values between $3.25 \%$ and $3.79 \%$ (Table 3), with no statistical difference between the months analyzed $(\mathrm{P}>0.05)$. Lactose was also not influenced by the stage of lactation ( $P>0.05$ ), resting at a mean of $4.58 \%$ throughout the lactation period (Table 3 ). A mean somatic cell count of $2.1 \times 10^{5} \mathrm{CS} / \mathrm{mL}$ was observed in the samples (Table 3), with no significant difference between evaluated months. The volume of milk remained constant, with no statistical difference from the start to the end of the lactation period ( $\mathrm{P}>0.05$ ), with a mean production of $28.15 \mathrm{~kg} / \mathrm{day}$ (Table 3).

Table 1. Milk and blood glutamine and glutamate concentrations in Holstein cows during the lactation.

\begin{tabular}{|c|c|c|c|c|c|c|}
\hline \multirow{2}{*}{ Lactation phase } & \multicolumn{3}{|c|}{ Milk $(\mu \mathrm{mol} / \mathrm{mL})$} & \multicolumn{3}{|c|}{ Blood $(\mu \mathrm{mol} / \mathrm{mL})$} \\
\hline & Gln & Glu & Gln+Glu & Gln & Glu & $\mathrm{Gln}+\mathrm{Glu}$ \\
\hline First & $0.089 \pm 0.025^{\mathrm{A}}$ & $0.441 \pm 0.075^{\mathrm{A}}$ & $0.531 \pm 0.079^{\mathrm{A}}$ & $0.265 \pm 0.034^{\mathrm{AB}}$ & $0.170 \pm 0.018^{\mathrm{A}}$ & $0.436 \pm 0.047^{\mathrm{A}}$ \\
\hline Second & $0.095 \pm 0.024^{\mathrm{A}}$ & $0.410 \pm 0.029^{\mathrm{A}}$ & $0.505 \pm 0.030^{\mathrm{A}}$ & $0.181 \pm 0.028^{\mathrm{B}}$ & $0.174 \pm 0.022^{\mathrm{A}}$ & $0.355 \pm 0.039^{A}$ \\
\hline Third & $0.169 \pm 0.052^{A}$ & $0.314 \pm 0.031^{\mathrm{A}}$ & $0.483 \pm 0.039^{\mathrm{A}}$ & $0.243 \pm 0.029^{\mathrm{AB}}$ & $0.157 \pm 0.015^{\mathrm{A}}$ & $0.401 \pm 0.044^{\mathrm{A}}$ \\
\hline Fifth & $0.105 \pm 0.032^{\mathrm{A}}$ & $0.369 \pm 0.061^{\mathrm{A}}$ & $0.474 \pm 0.071^{\mathrm{A}}$ & $0.190 \pm 0.031^{\mathrm{B}}$ & $0.176 \pm 0.017^{\mathrm{A}}$ & $0.366 \pm 0.040^{\mathrm{A}}$ \\
\hline Tenth & $0.148 \pm 0.023^{\mathrm{A}}$ & $0.366 \pm 0.029^{\mathrm{A}}$ & $0.514 \pm 0.041^{\mathrm{A}}$ & $0.276 \pm 0.028^{\mathrm{A}}$ & $0.157 \pm 0.009^{\mathrm{A}}$ & $0.433 \pm 0.029^{\mathrm{A}}$ \\
\hline
\end{tabular}

Different letters at the same columns represents $\mathrm{P}<0.05$ by Tukey test. Gln: glutamine; Glu: glutamate.

Table 2. Blood glutamine and glutamate concentrations in Hostein calves with 1 and 3 months old.

\begin{tabular}{|c|c|c|c|}
\hline & \multicolumn{3}{|c|}{ Blood amino acid $(\mu \mathrm{mol} / \mathrm{mL})$} \\
\hline & Gln & Glu & Gln + Glu \\
\hline First & $0.259 \pm 0.020^{\mathrm{A}}$ & $0.209 \pm 0.015^{\mathrm{A}}$ & $0.467 \pm 0.025^{\mathrm{A}}$ \\
\hline Third & $0.237 \pm 0.021^{\mathrm{A}}$ & $0.192 \pm 0.011^{\mathrm{A}}$ & $0.430 \pm 0.022^{\mathrm{A}}$ \\
\hline
\end{tabular}

Different letters at the same columns represents $\mathrm{P}<0.05$ by Tukey test. Gln: glutamine; Glu: glutamate. 
Table 3. Milk composition and production in Holstein cows during the lactation.

\begin{tabular}{|c|c|c|c|c|c|}
\hline \multirow{2}{*}{$\begin{array}{l}\text { Lactation period } \\
\text { (months) }\end{array}$} & \multicolumn{5}{|c|}{ Milk component } \\
\hline & Fat (\%) & Protein (\%) & Lactose (\%) & $\mathrm{SCC} \times 10^{5} / \mathrm{mL}$ & $\begin{array}{c}\text { Average of } \\
\text { production (kg/day) }\end{array}$ \\
\hline First & $3.26 \pm 0.16^{\mathrm{A}}$ & $2.98 \pm 0.08^{\mathrm{B}}$ & $4.56 \pm 0.07^{\mathrm{A}}$ & $2.3 \pm 0.80^{\mathrm{A}}$ & $27.00 \pm 2.65^{\mathrm{A}}$ \\
\hline Second & $3.25 \pm 0.13^{\mathrm{A}}$ & $2.94 \pm 0.08^{\mathrm{B}}$ & $4.66 \pm 0.03^{\mathrm{A}}$ & $2.7 \pm 0.18^{\mathrm{A}}$ & $30.20 \pm 2.68^{\mathrm{A}}$ \\
\hline Third & $3.47 \pm 0.23^{\mathrm{A}}$ & $2.99 \pm 0.07^{\mathrm{B}}$ & $4.58 \pm 0.20^{\mathrm{A}}$ & $1.1 \pm 0.34^{\mathrm{A}}$ & $28.86 \pm 2.09^{\mathrm{A}}$ \\
\hline Fifth & $3.51 \pm 0.16^{\mathrm{A}}$ & $3.61 \pm 0.08^{\mathrm{A}}$ & $4.55 \pm 0.03^{\mathrm{A}}$ & $2.4 \pm 0.10^{\mathrm{A}}$ & $28.02 \pm 2.19^{\mathrm{A}}$ \\
\hline Tenth & $3.79 \pm 0.15^{\mathrm{A}}$ & $3.61 \pm 0.07^{\mathrm{A}}$ & $4.55 \pm 0.42^{\mathrm{A}}$ & $2.1 \pm 0.76^{\mathrm{A}}$ & $26.71 \pm 2.17^{\mathrm{A}}$ \\
\hline
\end{tabular}

Different letters at the same columns represents $\mathrm{P}<0.05$ by Tukey test; SCC: somatic cell count.

\section{Discussion}

\subsection{Glutamine and Glutamate Concentration in Lactating Cows and in Calves}

Changes in blood [Gln] are associated with increase in utilization or decrease production of this amino acid in different species during lactation [4] [9]-[11]. In this research a significant reduction in blood [Gln] but not increase or decrease in milk [Gln] contribute to the idea that this amino acid was used to support milk production. Concentration of glutamine oscillates between the $2^{\text {nd }}$ and $5^{\text {th }}$ month of lactation, may indicating that Gln homeostasis is under stress during this period and in some periods consumption is large than production.

The plasma [Gln] in healthy individuals should vary from 0.300 to $0.800 \mu \mathrm{mol} / \mathrm{mL}$ in different species [12]. Similar to this actual research, [4] showed that [Gln] in lactating cows is low, between 0.190 to $0.300 \mu \mathrm{mol} / \mathrm{mL}$ and [10] showed significant decrease in plasma [Gln], from $\sim 0.300$ to $\sim 0.215 \mu \mathrm{mol} / \mathrm{mL}$, after calving. Reference [11] when investigating lactating sows, showed blood [Gln] between 0.300 to $0.600 \mu \mathrm{mol} / \mathrm{mL}$, and [9] found plasma [Gln] around $0.300 \mu \mathrm{mol} / \mathrm{mL}$ in lactating mares few days after parturition. One pitfall of this actual research was the impossibility to collect samples from these pregnant dairy cows and use this sample as control concentration, but blood [Gln] in the calves may be used to understand the results in the dairy cows.

Decrease of plasma glutamine in the immediate post-partum would is associated with large utilization of amino acids for different functions like: protein synthesis in the milk, increase in size of the mammary gland, intestinal activity and increased energy expenditure in the entire body [13]. Considering that the cows in this study are high production animals, under tropical conditions, their energy needs could be increased for milk production and Gln may contribute to increase the energy supplementation during lactation period. Finally, [14] reported that Gln is used as a metabolic regulator to increase the synthesis and reduce catabolism of proteins, and its use remains high during the entire lactation period, may decreasing its blood concentrations.

Glutamine is the most abundant amino acid found in the milk of most species [15]. However, in this actual study [Gln] found in low concentrations in the milk samples analyzed, below $0.200 \mu \mathrm{mol} / \mathrm{mL}$, when compared with values reported in other species [9] [11], but it is important to remember that Gln was not measured in colostrum from these dairy cows. Reference [9] showed large concentration of Gln in mare's colostrum associated with large decreased after 3 and 6 months of lactation. In contrast, [11] showed an increase in [Gln] and in [Glu] after parturition in lactating sows, but in this species lactation is shorter when compared with dairy cows and mares.

Glutamine and Glutamate, according to [16], are fundamental for milk production; approximately 25\% of casein is made up of glutamine and glutamate. This protein is the most important one in milk, used mainly to nourish calves, as well as for production of derivatives in the milk industry. In horses, It was showed large concentration of glutamine synthetase in mares' mammary gland [9] but we do not have information about this enzyme in dairy cows' mammary gland.

Supplementation with Gln in dairy cows may be associated with changes in blood and milk [Gln] but there are little studies about Gln supplemention in domestic animals. Reference [10] did not identify statistical differences in milk production and protein quantity between dairy cows that received Gln supplementation and those that did not. However, these authors did observe an increase of approximately 55\% in plasma [Gln] in the animals who received supplementation. In another study with lactating sows, [11] showed that supplementation with one combination of Gln and Glu produced increase in [Gln] both in their blood and their milk. It should be 
emphasized that studies with various species have demonstrated the benefits of glutamine supplementation, whether by enteral or parenteral nutrition, leading to better growth, repair and function of the intestinal mucosa [17] but to better understand the Gln metabolism in ruminants more studies are needed.

\subsection{Milk Production and Composition}

According to literature, milk production in bovines gradually increases until it reaches its peak around the second month of lactation, with a later decrease, though this characteristic was not observed in the studied herds, where there is no statistical difference between all five months studied. Mean milk production was $\sim 28.15 \mathrm{~kg} /$ cow/day, and it is higher than what was previously observed [18] who found a mean of $19.36 \mathrm{~kg} / \mathrm{cow} / \mathrm{day}$. Reference [19] using alfalfa hay as forage, obtained a smaller daily milk volume (21.26 kg) than the mean observed in this actual research. However, it is important to remember that level of milk production reflects the management conditions and genetic potential and milk production observed in actual research may reflected animals' nutrition and genetic.

Lactose is the milk component that least varies during the lactation period [20]. Also it is considered an osmotic factor, its concentration will affect whether or not water is removed from the mammary epithelial cells, interfering in the volume of milk produced [21]. The mean lactose value $(\sim 4.58 \%)$ in this actual research was above that established by the MAPA Normative Instruction n. 62/2011, demonstrating that the national standards for milk production were met in farms. Reference [18] also found a mean of $\sim 4.58 \%$, however, they observed a significant drop after the third month, with a mean lactose of $\sim 4.48 \%$, which differs from what was already observed [19] and in the present study, where the means remained stable.

There was no statistical difference between the analyzed samples regarding fat content, however, [20] considers this component to be the one that most varies in the milk, as previously verified [18], who observed a significant increase from the first to the tenth month of lactation. Reference [19] also found higher values for this milk component (3.61\%). Nonetheless, the mean fat quantity in the herds included in this research was above the minimal national requirements [22]. In addition, variation in fat content is considered normal, however, milk with a stable fat content, as seen in this study, can have an aggregated value for sales to the dairy derivatives industry, as it allows the quality of these derivatives to be maintained. As such, a high fat content represents more flavor and better consistency to the derivatives and a stable value represents the standardization of the products.

A higher protein content in the final stages of lactation $(\sim 3.61 \%)$, despite the literature suggesting that protein content would be higher in the initial stages due to production of the colostrum. This is justified by the fact that the samples are collected from females with at least 5 days of lactation as to avoid getting colostrum in the analysis, a requirement of the Pernambuco State Official Milk Control, since colostrum has different characteristics than milk regarding quantity and type of its components. Higher protein levels were also identified at the end of lactation by [18], with values $2.99 \%, 3.10 \%$ and $3.32 \%$ (in the first, fifth, and tenth month, respectively), while in actual research it was obtained higher values at $5^{\text {th }}$ and $10^{\text {th }}$ months.

The precursors to the synthesis of milk proteins are free amino acids in the blood and serum proteins (in $90 \%$ and 10\%, respectively). Essential amino acids are absorbed from the blood, while non-essential amino acids, such as Gln and Glu, are absorbed as free amino acids in the blood or synthetized by the mammary gland [21]. In our research we measured free Gln and Gln, but the amount of this amino acid may be higher if it was determined Gln and Glu in milk protein. Finally, it is important remember that amino acid component can be influenced by various factors, whether nutritional, environmental, or stress [23] [24]. Reference [25] suggest that there is a decrease in the quantity of amino acids in dairy cows' blood in the immediate post-partum, which could be another cause for the lower protein content seen in our samples in the initial months of lactation, but in this actual research blood [Gln] decreased and did not produce changes in milk [Gln] and protein percentage do not follow that was showed in blood [Gln].

The somatic cell count (SCC) has been considered a standard measure of quality because it is related to milk composition and industrial performance and to food safety, and is also indicative of the sanitary conditions of the mammary glands [26]. Mastitis changes milk composition by modifying the permeability of blood vessels and altering synthesis in the secreting tissue [27]. In this actual research there was no statistical difference in SCC concentration during all period studied, but [28] reporting a tendency for a high SCC at the start of lactation, with a decrease until the sixth week and a linear increase until the milk dries. The SSC concentration, observed in these two farms in Pernambuco, were below those established by the Brazilian Department of Agri- 
culture (NI n.62/2011) for the Northeast region, which determines a maximum $7.5 \times 10^{5} \mathrm{SC} / \mathrm{mL}$. This fact is important because showed that animals used in this research were healthy and do not have significant disease at their mammary gland, which can interfere in Gln concentration in blood and milk.

Finally, different reports showed that in the absence of infections, SCC varies little during the lactation period, such as was observed in this study, as well as being within the normal range for a healthy mammary gland $\left(\sim 2.50 \times 10^{5} \mathrm{SC} / \mathrm{mL}\right)$ and values higher than these should indicate the presence of subclinical mastitis in the herd [29]. Also there is no significative correlation between SSC and other milk components in this study. This is in accordance with [23], who also did not observe an effect of the somatic cell count on milk production and fat content. Reference [30] identified a relationship between increase of the SCC and milk constituents, just as [31] found an inversely proportional relationship between SCC and fat content, which was not observed in this research.

\section{Conclusion}

We concluded that the lactation period produced significant changes in blood [Gln] but not in the milk, contributing to the idea that this amino acid may be used intensively to the milk production. The absence of changes in milk [Gln] and [Glu] may have some association with no significant changes in calves' blood [Gln] and [Glu]. Fat, lactose, and somatic cell count were also not affected by lactation period. The protein percentage increased at the end of lactation, but they did not follow changes in blood or milk [Gln] variations. Finally, the metabolism of glutamine in dairy cows during lactation deserves to be further studied, in order to better understand how it is used and how it can be supplemented.

\section{Acknowledgements}

The authors would like to thank the Fazenda Oasis, Gravatá-PE, and Fazenda Cachoeira, São Bento do Una-PE. Financial Support: Ajinomoto do Brasil, Guabi Nutrição Animal and the FACEPE—Fundação de Amparo a Pesquisa do Estado de Pernambuco.

\section{References}

[1] Davis, T.A., Nguyen, H.V., Garcia-Bravo, R., Fiorotto, M.L., Jacksonz, E.M. and Reeds, P.J. (1994) Amino Acid Composition of the Milk of Some Mammalian Species Changes with Stage of Lactation. British Journal of Nutrition, 72, 845-853. http://dx.doi.org/10.1079/BJN19940089

[2] Clowes, E.J., Aherne, F.X., Schaefer, A.L., Foxcroft, G.R. and Baracos, V.E. (2003) Parturition Body Size and Body Protein Loss during Lactation Influence Performance during Lactation and Ovarian Function at Weaning in First Parity Sows. Journal of Animal Science, 81, 1517-1528.

[3] Chilliard, Y., Remond, B., Sauvant, D. and Vermorel, M. (1983) Particularités du Métabolisme Energetique. In: Particularités Nutritionnelles des Vaches a Haut Potentiel de Production. Bulletin Technique CRZV, 53, 37-64.

[4] Meijer, G.A.L., Van Der Meulen, J., Bakker, J.G.M., Van Der Koelen, C.J. and Van Vuuren, A.M. (1995) Free Amino Acids in Plasma and Muscle of High Yielding Dairy Cows in Early Lactation. Journal of Dairy Science, 78, 11311141. http://dx.doi.org/10.3168/jds.S0022-0302(95)76730-3

[5] Albertini, S.M. and Ruiz, M.A. (2001) The Role of Glutamine in Nutritional Therapy in Bone Marrow Transplant. Brazilian Journal of Hematology and Hemotherapy, 23, 41-47.

[6] Walsh, N.P., Blannin, A.K., Robson, P.J. and Gleeson, M. (1998) Glutamine, Exercise and Immune Function: Links and Possible Mechanisms. Sports Medicine, 26, 177-191. http://dx.doi.org/10.2165/00007256-199826030-00004

[7] Rogerio, M.M. and Tirapegui, J.O. (2003) Nutritional and Biochemical Considerations of Glutamine Supplementation in Athletes: Controversies and Current Aspects. Journal of Nutrition and Metabolism, 7, 106-117.

[8] Lago, E.P., Pires, A.V., Susin, I., Faria, V.P. and Lago, L.A. (2001) Effect of Body Condition Score at Calving on Energy Metabolism, Milk Yield and Disease Occurrence in Postpartum of Dairy Cows. Revista Brasileira de Zootecnia, 30, 1544-1549. http://dx.doi.org/10.1590/S1516-35982001000600023

[9] Manso Filho, H.C., Mckeever, K.H., Gordon, M.E., Costa, H.E.C., Lagakos, W.S. and Watford, M. (2008) Changes in Glutamine Metabolism Indicate a Mild Catabolic State in the Transition Mare. Journal Animal Science, 86, 3424-3431. http://dx.doi.org/10.2527/jas.20080-1054

[10] Doepel, L., Lessard, M., Gagnon, N., Lobley, G.E., Bernier, J.F., Dubreuil, P. and Lapierre, H. (2006) Effect of PostRuminal Glutamine Supplementation on Immune Response and Milk Production in Dairy Cows. Journal of Dairy 
Science, 89, 3107-3121. http://dx.doi.org/10.3168/jds.S0022-0302(06)72585-1

[11] Manso, H.E.C.C.C., Manso Filho, H., Carvalho, L.C., Kutschenk, M., Nogueira, E.T. and Walford, M. (2012) Glutamine and Glutamate Supplementation Raise Milk Glutamine Concentrations in Lactating Gilts. Journal of Animal Science and Biotechnology, 3, 2. http://dx.doi.org/10.1186/2049-1891-3-2

[12] Watford, M., Kutschenko, M. and Nogueira, E.T. (2011) Optimal Dietary Glutamine for Growth and Development. Revista Brasileira de Zootecnia, 40, 384-390.

[13] Plaizier, J.C., Walton, J.P. and Mcbride, B.W. (2001) Effect of Post-Ruminal Infusion of Glutamine on Plasma Amino Acids, Milk Yield and Composition in Lactating Dairy Cows. Canadian Journal of Animal Science, 81, 229-235. http://dx.doi.org/10.4141/A00-073

[14] Zavarize, K.C., Menten, J.F.M., Traldi, A.B., Santarosa, J. and Silva, C.L.S. (2010) Administration of Glutamine in the Nutrition of Monogastric Animals. Revista Portuguesa de Ciências Veterinárias, 105, 5-10.

[15] Wu, G., Knabe, D.A., Yan, W. and Flynn, N.E. (1995) Glutamine and Glucose Metabolism in Enterocytes of the Neonatal Pig. American Journal of Physiology-Regulatory, Integrative and Comparative Physiology, 268, R334-R342.

[16] Eigel, W.N., Butler, J.E., Ernstrom, C.A., Farrell, H.M., Harwalkar, J.R.V.R., Jenness, R. and Whitney, R. (1984) Nomenclature of Proteins of Cow’s Milk: Fifth Revision. Journal of Dairy Science, 67, 1599-1631. http://dx.doi.org/10.3168/jds.S0022-0302(84)81485-X

[17] Ziegler, T.R., Bazargan, N., Leader, L.M. and Martindale, R. (2000) Glutamine and the Gastrointestinal Tract. Current Opinion in Clinical Nutrition \& Metabolic Care, 3, 355-362. http://dx.doi.org/10.1097/00075197-200009000-00005

[18] Noro, G., González, F.H.D., Campos, R. and Dürr, J.W. (2006) Effects of Environmental Factors on Milk Yield and Composition of Dairy Herds Assisted by Cooperatives in Rio Grande do Sul, Brazil. Revista Brasileira de Zootecnia, 35, 1129-1135. http://dx.doi.org/10.1590/S1516-35982006000400026

[19] Jobim, C.C., Ferreira, G.A., Santos, G.T., Cecato, U. and Damasceno, J.C. (2002) Milk Production and Composition in Dutch Breed Cows Fed with Alfafa and Tifton-85 Hay and Corn Silage. Acta Scientiarum, 24, 1039-1043.

[20] Prata, L.F. and Fukuda, R.T. (2001) Fundamentos da Ciência do Leite. Unesp-Editora Universitária, Jaboticabal.

[21] Gonzalez, F.H.D., Dürr, J.W. and Fontaneli, R.S. (2001) Uso do Leite para Monitorar a Nutrição e o Metabolismo de Vacas Leiteiras. Editora da UFRGS, Porto Alegre.

[22] Brazil (2011) Instrução normativa no 62, de 29 de dezembro de 2011. Regulamento Técnico de Identidade e Qualidade de Leite Cru Refrigerado. Ministério da Agricultura, Pecuária e Abastecimento. Diário Oficial da União, Seção 1, Brasília, 6-11.

[23] Pereira, A.R., Machado, P.F. and Barancelli, G. (1997) Somatic Cell Count and Milk Quality. Revista dos Criadores, 67, 19-21.

[24] Santos, M.V. and Fonseca, L.F.L. (2006) Estratégias para o Controle de Mastite e Melhoria da Qualidade do Leite. Editora Manole, Barueri.

[25] Doepel, L., Lapierre, H. and Kennelly, J.J. (2002) Peripartum Performance and Metabolism of Dairy Cows in Response to Prepartum Energy and Protein Intake. Journal of Dairy Science, 85, 2315-2334. http://dx.doi.org/10.3168/jds.S0022-0302(02)74312-9

[26] Santos, M.V. (2001) Somatic Cell Count and Quality of Milk and Derivatives. Simpósio Internacional Sobre Produção Intensiva de Leite, Belo Horizonte, 115-127.

[27] Machado, P.F., Pereira, A.R. and Sarríes, G.A. (2000) Bulk Tank Milk Composition from Brazilian Herds Distributed by Its Somatic Cell Count. Revista Brasileira de Zootecnia, 29, 1883-1886. http://dx.doi.org/10.1590/S1516-35982000000600038

[28] Texeira, N.M., Freitas, A.F. and Barra, R.B. (2003) Environmental Factors Influencing Monthly Variation of Milk Composition and Somatic Cell Counts in Herds of the State of Minas Gerais. Arquivo Brasileiro de Medicina Veterinária e Zootecnia, 55, 491-499.

[29] Magalhães, H.R., El Faro, L., Cardoso, V., de Paz, C.C.P., Cassoli, L.D. and Machado, P.F. (2006) Effects of Environmental Factors on Somatic Cell Count and Reduction of Milk Yield on Holstein Cows. Revista Brasileira de Zootecnia, 35, 415-421. http://dx.doi.org/10.1590/S1516-35982006000200011

[30] Silva, L.C.R., Furuya, W.M., Natali, M.R.M., Schamber, C.R., Dos Santos, L.D. and Vidal, L.V.O. (2010) Productive Performance and Intestinal Morphology of Nile Tilapia Juvenile Fed Diets with L-Glutamine and L-Glutamate. Revista Brasileira de Zootecnia, 39, 1175-1179. http://dx.doi.org/10.1590/S1516-35982010000600002

[31] Pereira, A.R., Machado, P.F. and Sarríes, G.A. (2001) Somatic Cell Count and Production Characteristics of Lactating Holstein Cows. Scientia Agricola, 58, 649-654. http://dx.doi.org/10.1590/S0103-90162001000400001 
Scientific Research Publishing (SCIRP) is one of the largest Open Access journal publishers. It is currently publishing more than 200 open access, online, peer-reviewed journals covering a wide range of academic disciplines. SCIRP serves the worldwide academic communities and contributes to the progress and application of science with its publication.

Other selected journals from SCIRP are listed as below. Submit your manuscript to us via either submit@scirp.org or Online Submission Portal.
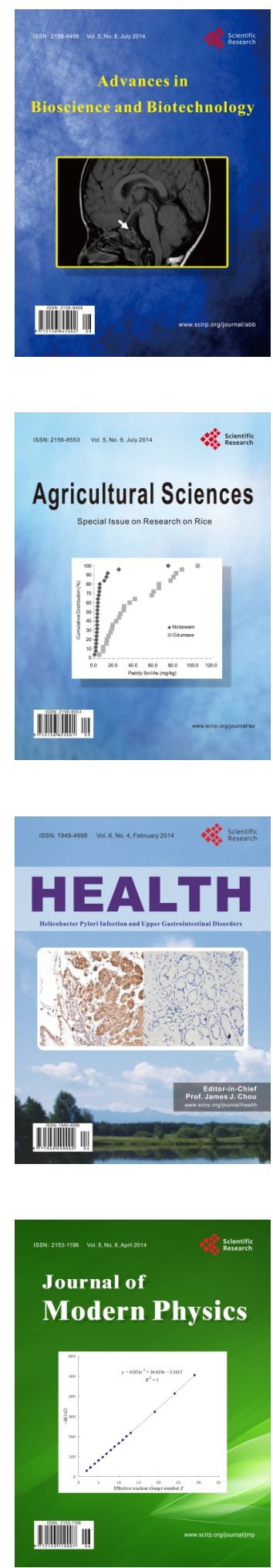
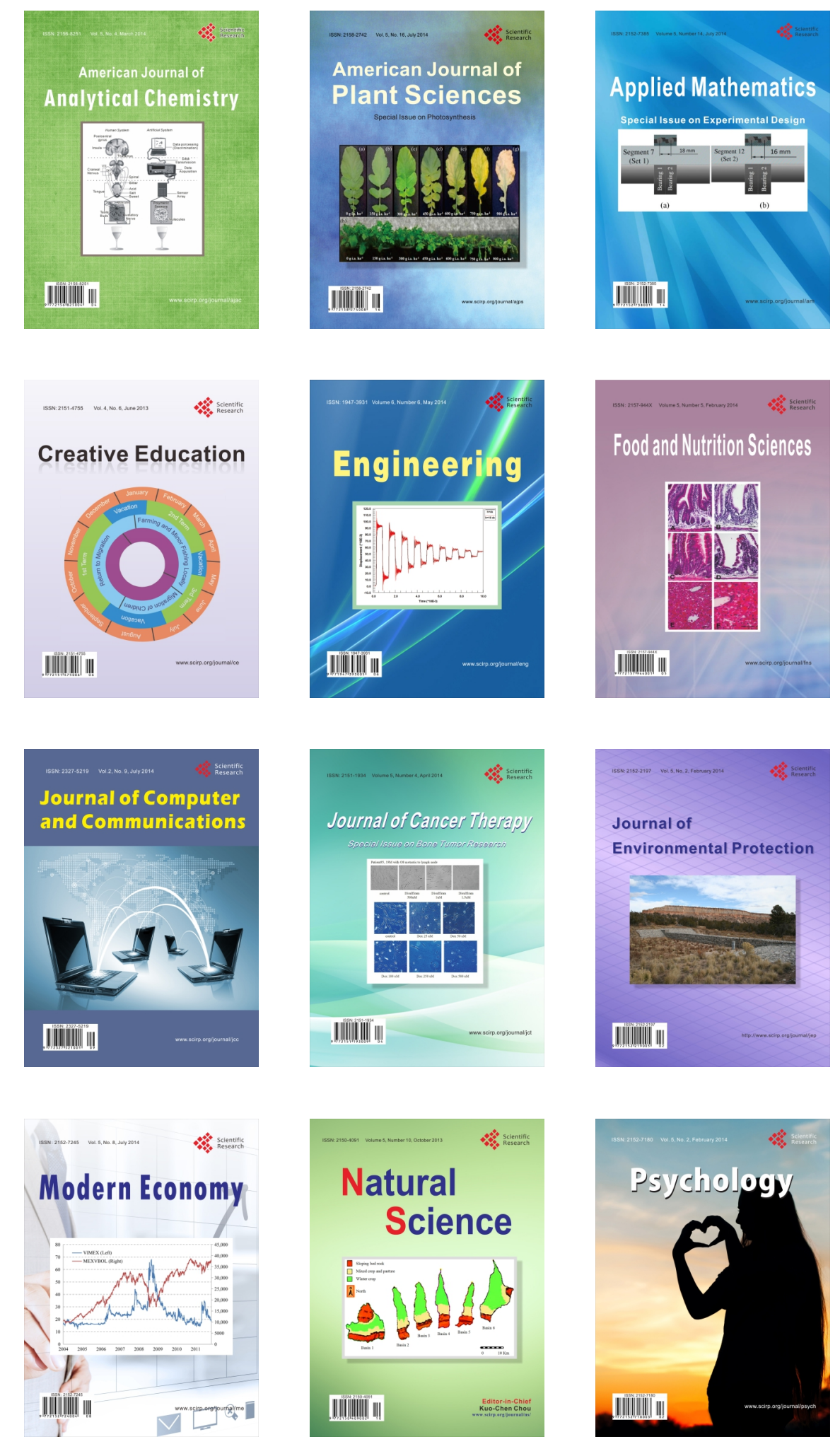